\title{
Effect of Interseed Spacing, Tissue Perfusion, Thermoseed Temperatures and Catheters in Ferromagnetic Hyperthermia: Results from Simulations Using Finite Element Models of Thermoseeds and Catheters
}

Dean T. Tompkins, Ray Vanderby, Sandy A. Klein, William A. Beckman, Richard A. Steeves, and Bhudatt R. Paliwal

\begin{abstract}
Finite element heat-transfer models of ferromagnetic thermoseeds and catheters are developed for simulating ferromagnetic hyperthermia. These models are implemented into a general purpose, finite element computer program to solve the bioheat transfer equation. The seed and catheter models are unique in that they have fewer modeling constraints than other previously developed thermal models. Simulations are conducted with a $4 \times 4$ array of seeds in a multicompartment tissue model. The heat transfer model predicts that fractions of tumor greater than $43^{\circ} \mathrm{C}$ are between 8 and $40 \%$ lower when seed temperatures depend on power versus models which assume a constant seed temperature. Fractions of tumor greater than $42^{\circ} \mathrm{C}$, in simulations using seed and catheter models, are between 3.3 and $25 \%$ lower than in simulations with bare seeds. It is demonstrated that an array of seeds with Curie points of $62.6^{\circ} \mathrm{C}$ heats the tumor very well over nearly all blood perfusion cases studied. In summary, results herein suggest that thermal models simulating ferromagnetic hyperthermia should consider the power-temperature dependence of seeds and include explicit models of catheters.
\end{abstract}

\section{NOMENCLATURE}

a Radius of thermoseed (mm).

$A_{c, c} \quad$ Cross-sectional area of catheter model $\left(\mathrm{m}^{2}\right)$.

$A_{c, s} \quad$ Cross-sectional area of cylindrical thermoseed $\left(\mathrm{m}^{2}\right)$.

$A_{c, \text { dod }} \quad$ Cross-sectional area of dodecagonal thermoseed model $\left(\mathrm{m}^{2}\right)$.

$A_{\text {s }} \quad$ Boundary-segment area of a thermoseed and a finite element node on the seed surface $\left(\mathrm{m}^{2}\right)$.

bei, ber Kelvin functions (dimensionless).

$b e i^{\prime}$, ber' First derivative of Kelvin functions (dimensionless).

$c_{b} \quad$ Specific heat of blood $\left(\mathrm{J} / \mathrm{kg} /{ }^{\circ} \mathrm{C}\right)$

$f \quad$ Frequency of electromagnetic field $(\mathrm{Hz})$.

Manuscript received March 16, 1993; June 21, 1994. This work was supported in part by NIH grant CA49429.

D. T. Tompkins is with the Departments of Mechanical Engineering and Human Oncology, University of Wisconsin-Madison, WI 53792 USA.

R. Vanderby, S. A. Klein, and W. A. Beckman are with the Department of Mechanical Engineering, University of Wisconsin-Madison, WI 53792 USA. R. A. Steeves and B. R. Paliwal are with the Department of Human Oncology, University of Wisconsin-Madison, G5/330, Madison, WI 53792 USA.

IEEE Log Number 9404273. $h \quad$ Conductance coefficient between a thermoseed and the finite element nodes on the seed surface $\left(\mathrm{J} / \mathrm{s} / \mathrm{m}^{2} /{ }^{\circ} \mathrm{C}\right)$.

$H_{0} \quad$ Amplitude of magnetic field (A/m).

$i \quad$ Unit length $(\mathrm{m})$.

$I_{0}, I_{1} \quad$ Modified Bessel functions of the First Kind of order 0 and 1 , respectively (dimensionless).

$j \quad$ Iteration counter used in Newton-Raphson scheme (dimensionless).

$k_{c} \quad$ Thermal conductivity of catheter model $\left(\mathrm{W} / \mathrm{m} /{ }^{\circ} \mathrm{C}\right)$.

$k_{t} \quad$ Thermal conductivity of tissue $\left(\mathrm{W} / \mathrm{m} /{ }^{\circ} \mathrm{C}\right)$.

$K_{0}, K_{1} \quad$ Modified Bessel functions of the Second Kind of order 0 and 1 , respectively (dimensionless).

$l \quad$ Distance between thermoseeds (mm).

$L_{N} \quad$ Length of normal tissue model (mm).

$L_{T} \quad$ Length of tumor model (mm).

$M \quad$ Magnetization of thermoseed (tesla).

$n \quad$ Energy flow parameter $\left(=\sqrt{W c_{b} / k_{t}}\right)(1 / \mathrm{m})$.

$P^{\prime} \quad$ Energy absorption rate of thermoseed per unit length $(\mathrm{J} / \mathrm{s} / \mathrm{m})$.

$P^{\prime}{ }_{s, j} \quad$ Energy absorption rate of thermoseed $s$ and iteration $j(\mathrm{~J} / \mathrm{s} / \mathrm{m})$.

$q_{a} \quad$ Energy absorption rate per unit volume of themoseed $\left(\mathrm{J} / \mathrm{s} / \mathrm{m}^{3}\right)$.

$r \quad$ Denotes radial direction $(\mathrm{m})$.

$R \quad$ Outer radius of cylindrical tissue model (m).

$s \quad$ Thermoseed number (dimensionless).

$S \quad$ Total number of thermoseeds (dimensionless).

$t_{c} \quad$ Thickness of annular-shaped catheter shell (mm).

$T \quad$ Tissue temperature $\left({ }^{\circ} \mathrm{C}\right)$.

$T_{b} \quad$ Blood temperature $\left({ }^{\circ} \mathrm{C}\right)$.

$T_{s} \quad$ Thermoseed temperature $\left({ }^{\circ} \mathrm{C}\right)$.

$T_{s, c . p .} \quad$ Curie temperature of thermoseed $\left({ }^{\circ} \mathrm{C}\right)$.

$T_{s, j} \quad$ Temperature of thermoseed $s$ and iteration $j\left({ }^{\circ} \mathrm{C}\right)$.

$T_{s, \nu} \quad$ Thermoseed surface temperature at finite element node $\nu\left({ }^{\circ} \mathrm{C}\right)$.

$W \quad$ Mass flow rate of blood per unit volume of 


\begin{tabular}{|c|c|}
\hline$x$ & $\begin{array}{l}\text { tissue }\left(\mathrm{kg} / \mathrm{s} / \mathrm{m}^{3}\right) \text {. } \\
\text { Denotes } x \text {-direction in rectangular coordinate } \\
\text { system }(\mathrm{m}) .\end{array}$ \\
\hline $\mathbf{x}$ & $\begin{array}{l}\text { Induction number }(=a \sqrt{\omega \sigma \mu}) \text { (dimension- } \\
\text { less). }\end{array}$ \\
\hline$y$ & $\begin{array}{l}\text { Denotes } y \text {-direction in rectangular coordinate } \\
\text { system }(\mathrm{m}) \text {. }\end{array}$ \\
\hline$\theta$ & Temperature difference $\left(=T-T_{b}\right)\left({ }^{\circ} \mathrm{C}\right)$. \\
\hline$\mu$ & $\begin{array}{l}\text { Magnetic permeability of thermoseed } \\
\text { (tesla-m/A). }\end{array}$ \\
\hline$\pi$ & $\begin{array}{l}\text { Ratio of circumference of circle to its diameter } \\
\text { (radians). }\end{array}$ \\
\hline$\rho_{b}$ & Density of blood $\left(\mathrm{kg} / \mathrm{m}^{3}\right)$. \\
\hline$\rho_{t}$ & Density of tissue $\left(\mathrm{kg} / \mathrm{m}^{3}\right)$. \\
\hline$\sigma$ & Electrical conductivity of thermoseed $(1 / \Omega / \mathrm{m})$. \\
\hline$\omega$ & Angular velocity $(=2 \pi f)(1 / \mathrm{s})$. \\
\hline
\end{tabular}

\section{INTRODUCTION}

I NTERSTITIAL hyperthermia can be produced with inductively heated ferromagnetic thermoseeds [1]-[4], localized current field heating between pairs of temporarily implanted metallic electrodes [5]-[10], temporarily implanted microwave antennas [6], [11]-[14], interstitial hot water perfusion [15], [16], laser irradiation via fiber-optics [17], and resistiveheating elements [18].

Ferromagnetic hyperthermia utilizes cylindrically shaped, metallic alloys, called thermoseeds, that are placed surgically into tumors. Supplying power to a coil placed around the patient creates an electromagnetic field that produces eddy-current heating within the thermoseeds. Tissues near the thermoseeds are then heated via thermal conduction. The temperature reached by a thermoseed is a function of several variables including the strength and frequency of the electromagnetic field, orientation of thermoseeds within the coil, proximity to other thermoseeds, permeability and electrical conductivity of the thermoseed, and local blood perfusion rate and thermophysical properties.

Self-regulating thermoseeds have the unique characteristic of heating to a temperature that is maintained within a few degrees. The ability of the thermoseeds to self-regulate is a consequence of their magnetic properties. Self-regulating thermoseeds are composed of Ni-Cu [2], Ni-Si [19], [20], NiPd [3] and other [21], [22] alloys. The Curie point can be made different for each thermoseed by altering the mass fraction of the diluent (e.g., $\mathrm{Cu}, \mathrm{Si}$ and $\mathrm{Pd}$ in alloys of $\mathrm{Ni}$ ) in the thermoseed. The operating temperature ${ }^{l}$ of a thermoseed is defined as the temperature at an absorbed power level of $10 \mathrm{~W} / \mathrm{m}$ in the power-versus-temperature plot of a thermoseed [23]-[25]. The ability of thermoseeds to self-regulate is advantageous since it is based upon an intrinsic material property of the implants. However, it is difficult to alter the temperature of individual seeds during a hyperthermia treatment since there is no physical contact with the seeds. There is therefore a need

${ }^{1}$ The operating temperature of a $(\mathrm{Ni}-\mathrm{Cu})$ thermoseed is generally between 2.5 and $5^{\circ} \mathrm{C}$ lower than the Curie point. The operating temperature, in addition to the Curie point, is used in this paper because seed temperatures are closer to the operating temperature than the Curie point in simulations of hyperthermia treatments herein. to predict temperature distributions a priori. One step toward satisfying this need is developing a heat-transfer model of ferromagnetic thermoseeds.

Thermal models of ferromagnetic thermoseeds have been developed previously [1], [2], [26]-[36] and are summarized in Table I. Some seed models have used a constantpower modeling assumption [1], [2], [29]. Other thermal models employ a constant-temperature modeling assumption [2], [26]-[29], [35]. Still other thermal models incorporate the self-regulating feature of seeds [2], [35], [36]. The constanttemperature and self-regulating modeling assumptions have been shown to produce better tumor temperature distributions than those using the constant power assumption [2], [29]. Some studies have suggested that seeds should incorporate the self-regulating feature in the thermal model and include the finite size of catheters [35], [36]. The goal of the present study is to develop a finite element thermal model that incorporates the finite size of seeds and catheters and models the selfregulating feature of seeds. The seed and catheter models developed herein have fewer modeling constraints than other models (see remarks in Table I).

In the present study, an analytical heat-transfer model of a single thermoseed implanted in tissue is developed. A finitesized, numerical thermal model of a seed and a catheter is presented. Temperature distributions from the analytical model are compared with those of the numerical seed model. In addition, simulations are performed with a multicompartment tissue model containing an array of seeds, where seed temperatures depend on the power absorbed. By considering the power absorption of thermoseeds, the temperatures of self-regulating seeds are not constrained by the constant-temperature assumption. The effects of 1) interseed spacing within the thermoseed array, 2) variations in blood perfusion rates, and 3) seed types (or Curie points) with and without catheters on thermoseed and tissue temperatures are demonstrated.

\section{Analytical Thermal model of a Single Catheterless Thermoseed IN TISSUE}

The tissue model in Fig. 1 is the radial cross-section of a cylindrically shaped tissue system in which the long axis of a thermoseed was placed along the centerline of the tissue. The following assumptions are made in the development of the analytical thermal model: i) the ferromagnetic thermoseed is $65 \mathrm{~mm}$ in length and the cross-section in Fig. 1 is at the central plane; therefore, thermal conduction is in the radial direction only since these conditions satisfy modeling constraints for heat transfer in one and two dimensions established previously [26], [34]); ii) energy enters and leaves the tissue model via blood perfusion; iii) the thermal conductivity, $k_{t}(0.64$ $\left.\mathrm{W} / \mathrm{m} /{ }^{\circ} \mathrm{C}\right)$, and density, $\rho_{t}\left(1080 \mathrm{~kg} / \mathrm{m}^{3}\right)$, of the tissue is that of resting muscle tissue and is constant and uniform throughout the tissue model; iv) the specific heat, $c_{b}\left(3900 \mathrm{~J} / \mathrm{kg} /{ }^{\circ} \mathrm{C}\right)$, and density, $\rho_{b}\left(1080 \mathrm{~kg} / \mathrm{m}^{3}\right)$, of blood is also constant and uniform; v) the tissue absorbs a negligible amount of energy at the electromagnetic field frequencies $(90 \mathrm{kHz})$ used in ferromagnetic hyperthermia; vi) the rate of energy dissipation by metabolic processes within the tissue is negligible [37]; 
TABLE I

Summary of Ferromagnetic Seed Models

\begin{tabular}{|c|c|c|c|c|c|c|c|c|c|c|}
\hline \multirow{3}{*}{ Model } & \multirow{3}{*}{ 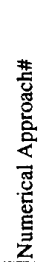 } & \multirow{3}{*}{ 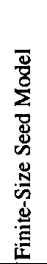 } & \multirow{3}{*}{ 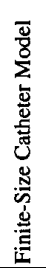 } & \multirow{2}{*}{\multicolumn{2}{|c|}{ 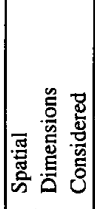 }} & \multicolumn{3}{|c|}{ 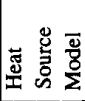 } & \multirow{3}{*}{ 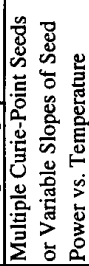 } & \multirow{3}{*}{ Remarks } \\
\hline & & & & & & $\begin{array}{l:}5 \\
0 \\
0 \\
0 \\
0 \\
0\end{array}$ & : & & & \\
\hline & & & & 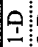 & مُ & है: & & & & \\
\hline Atkinson et al. [1] & A & $\sqrt{ } *$ & & & $\sqrt{ }$ & $\sqrt{1}$ & & & & $\begin{array}{l}{ }^{*} \text { Seed thermal properties indistinguishable } \\
\text { from tissue properties. }\end{array}$ \\
\hline Brezovich et al. [2] & A & $\sqrt{*}$ & & & $\checkmark$ & $\checkmark$ & $\sqrt{ }$ & $\sqrt{ }$ & & $\begin{array}{l}\text { *Seed thermal properties indistinguishable } \\
\text { from tissue properties. }\end{array}$ \\
\hline Babbs et al. [18] & FD & & $\sqrt{*}$ & & $\sqrt{ }$ & & $\sqrt{ }$ & & & $\begin{array}{lll}{ }^{*} \text { Methods not developed explicitly for } \\
\text { ferromagnetic heating. }\end{array}$ \\
\hline Chin and Stauffer [26] & $\mathrm{FE}^{\wedge}$ & $\sqrt{ }$ & & & $\sqrt{ }{ }^{\prime}$ & & $\sqrt{ }$ & & $\sqrt{ }$ & $\begin{array}{l}\text { *3-D problem collapsed to } 2-\mathrm{D} \text { due to } \\
\text { circumferential symmetry. }\end{array}$ \\
\hline Mechling and Strohbehn [27] & FE & $\sqrt{ } *$ & & & $v$ & & $\sqrt{*}$ & & $\sqrt{*}$ & $\begin{array}{l}{ }^{*} \text { Heating power produced by seed adjusted } \\
\text { until tissue temperature constraint was met. }\end{array}$ \\
\hline Vanderby et al. [28] & $\mathrm{FE}$ & & & & $\sqrt{*}$ & & $\sqrt{ }$ & & $\sqrt{ }$ & *Seeds modeled as point sources. \\
\hline Matloubieh et al. [29] & $\mathrm{FD}^{\wedge}$ & $\sqrt{*}$ & & & $\sqrt{ }$ & $\sqrt{ }$ & $\sqrt{ }$ & & $\sqrt{ }$ & $\begin{array}{l}\text { *Thermal resistance concepts employed } \\
\text { between adjacent nodes. }\end{array}$ \\
\hline Haider et al. [35] & A & $\sqrt{ }$ & $\sqrt{ }$ & $\sqrt{*} *$ & & & $\sqrt{ }$ & $\sqrt{ }$ & $\sqrt{ }$ & $\begin{array}{l}\text { *Some results are compared to a 3-D FD model } \\
\text { (Chen et al. [36]). }\end{array}$ \\
\hline Chen et al. [36] & $\mathrm{FD}^{\wedge}$ & $\sqrt{*}$ & $\sqrt{*}$ & & $\sqrt{ }$ & & & $\sqrt{ }$ & $\sqrt{ }$ & $\begin{array}{l}\text { *"Distributed source" approximation used } \\
\text { which imposes a "wall constraint". }\end{array}$ \\
\hline Present Study & $\mathrm{FE}^{\wedge}$ & $\sqrt{ }$ & $\sqrt{ }$ & $\sqrt{1}$ & $\sqrt{ }$ & & $\sqrt{ }$ & $\sqrt{ }$ & $\sqrt{ }$ & \\
\hline
\end{tabular}

\#A - Analytical; FD - Finite Difference; FE - Finite Element

^Accuracy of numerical solutions validated with analytical solutions and/or mesh reduction studies.

vii) the blood temperature, $T_{b}$, is constant and equal to the body core temperature of $37^{\circ} \mathrm{C}$; and viii) the thermal contact resistance at the interface of the thermoseed and tissue is negligible.

\section{A. Modeling the Thermoseed $(0 \leq r \leq a)$}

The thermoseed is modeled as a thermally lumped ${ }^{2}$ material because of its high thermal conductivity and its small diameter $(=2 a)$. Thus, the thermal conductivity of the seed is assumed to be infinite since there is negligible temperature gradient in the radial direction within the seed. The seed is modeled with zero blood perfusion. The thermoseed is also modeled with an energy absorption rate per unit volume which is numerically equal to the energy absorption rate per unit length, $P^{\prime}$, divided by the cross-sectional area of a cylindrical thermoseed; $A_{c, s}$. Since the thermoseeds are heated inductively by eddy currents, a heat flux, $q^{\prime \prime}$, is produced uniformly at the outer radius of the seed.

\section{B. Modeling the Tissue $(a \leq r \leq R)$}

An energy balance on the control volume in the tissue model of Fig. 1 under steady-state conditions and assumptions i)

${ }^{2}$ The term, lumped, is commonly used in heat transfer texts [38] to describe a material that has no temperature gradient within its structure. Thus, lumped is analogous to the term uniform.

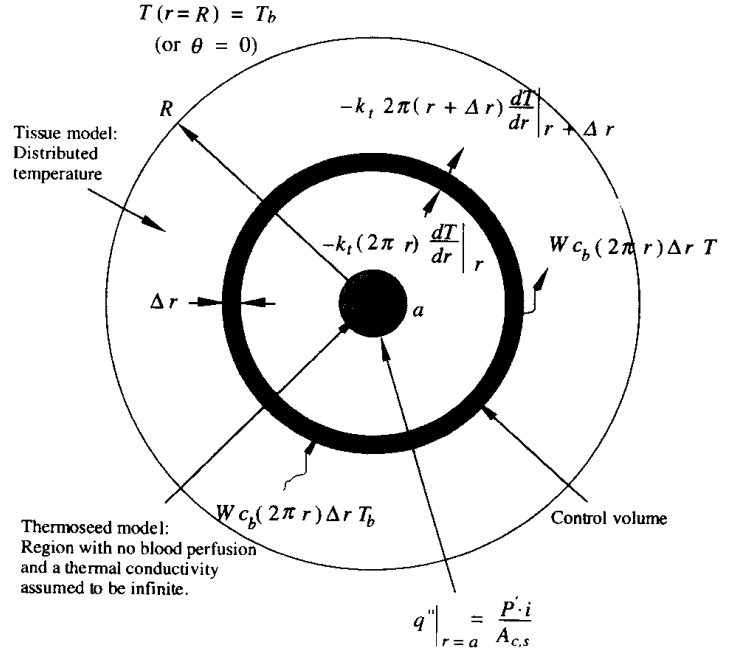

Fig. 1. Description of analytical thermoseed and tissue models. The seed $(0$ $\leq r \leq a$ ) is not perfused and is assumed to have an infinite thermal conductivity, and thus will have a lumped (or uniform) temperature $\left(T_{s}=T_{s}\left(P^{\prime}\right)\right.$ ). The seed is modeled with an energy absorption rate $\left(=P^{\prime} / A_{c, s}\right)$. The tissue model $(a \leq r \leq R)$ is a region of distributed temperature with conductive and convective-like $\left(W_{c_{b}}\right)$ energy transport as shown leaving and entering the control volume over which the energy balance is performed. 
through viii) yields

$$
\frac{d}{d r}\left(r \frac{d T}{d r}\right)-n^{2} r\left(T-T_{6}\right)=0
$$

In (1), $r$ is the radial length and $n$ is a parameter equal to $\sqrt{W c_{b} / k_{t}}$ where $W$ is the mass flow rate of blood per unit volume of tissue [39]. Substituting $\theta(r)=T(r)-T_{b}$, (1) becomes

$$
\frac{d}{d r}\left(r \frac{d \theta}{d r}\right)-n^{2} r \theta(r)=0
$$

The outer radius, $R$, of the tissue model is assumed to have a temperature equal to body core temperature $\left(T_{b}\right)$. Thus, the boundary conditions for (2) are

$$
\begin{array}{ll}
r=a: & q^{\prime \prime}=\frac{P^{\prime} \cdot i}{A_{c, s}}=-\left.k_{t} \frac{d \theta}{d r}\right|_{r=a} \\
r=R: & \theta=0 .
\end{array}
$$

In (3a), $i$ is a unit length multiplier. The solution to (2) for the temperature distribution (above $T_{b}$ ) in the tissue as a function of radial distance is

$$
\theta(r)=\frac{P^{\prime} a}{2 A_{c, s} n k_{t}} \frac{\left[I_{0}(n R) K_{0}(n r)-K_{0}(n R) I_{0}(n r)\right]}{\left[I_{1}(n a) K_{0}(n R)+I_{0}(n R) K_{1}(n a)\right]} .
$$

In (4), $I_{0}$ and $K_{0}$ are modified Bessel functions of the first and second kind of order 0 , respectively, and $I_{1}$ and $K_{1}$ are modified Bessel functions of the first and second kind of order 1 , respectively [40].

The analytical model is not useful in modeling the heat transfer from ferromagnetic sources in general. That is, the assumption that the temperature distribution in the tissue depends only on one direction $(r)$ is invalid for irregular thermoseed array configurations and unsymmetrical tissue geometries with nonuniform thermal conductivity and blood perfusion. The purpose of the analytical model is to validate the numerical seed model in a simple tissue system where the temperature distribution is radially dependent.

\section{NUMERICAL THERMAL MODEL OF THERMOSEEDS AND CATHETERS IN TISSUE}

\section{A. Modeling the Thermoseed}

Although thermoseeds are circular in radial cross-section, the finite element model uses linear elements. Thus, the finitesized numerical thermal model of a seed is approximated by straight-line segments. A dodecagon (12-sided polygon) is investigated as a model for thermoseeds (Fig. 2). The crosssectional area of the dodecagonal seed model is $A_{c, d o d}$ and is equal to the cross-sectional area of a cylindrical thermoseed $\left(A_{c, s}\right)$.

As with the analytical seed model, the thermoseed is modeled as a thermally lumped material because of its high thermal conductivity and its small diameter. Again, the thermal conductivity of the seed is assumed to be infinite. The seed is also modeled with zero blood perfusion and with an energy absorption rate per unit volume $\left(q_{a}\right)$ which is numerically equal to the energy absorption rate per unit length $\left(P^{\prime}\right)$ divided by the cross-sectional area of the seed $\left(A_{c, \text { dod }}\right)$.
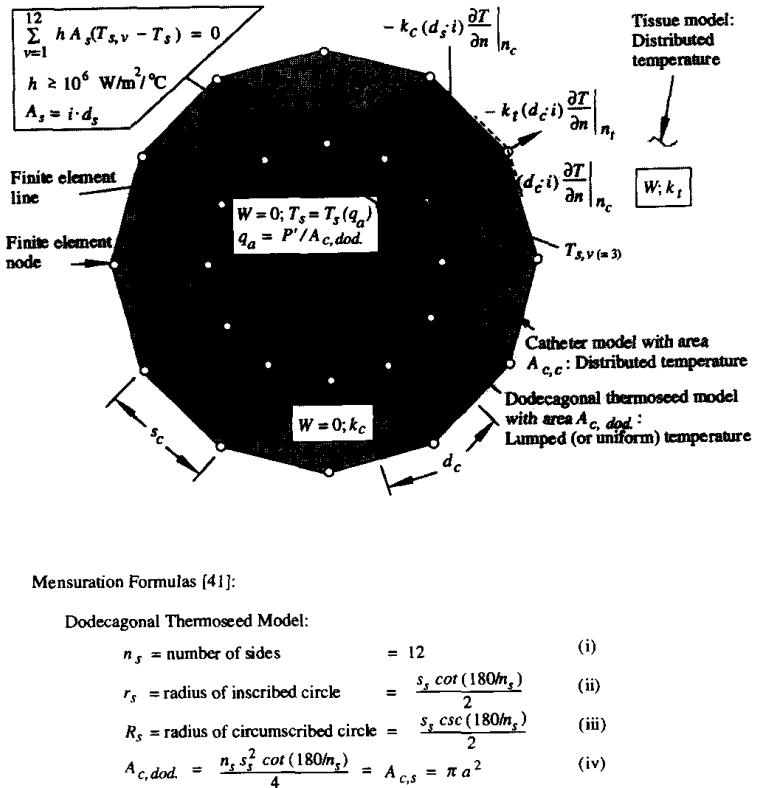

Catheter Model:

$$
\begin{aligned}
& n_{c}=\text { number of sides } \quad=12 \\
& r_{c}=\text { radius of inscribed circle }=\frac{s_{c} \cot \left(180 / n_{c}\right)}{2} \\
& R_{c}=\text { radius of circumscribed circle }=\frac{s_{c} \csc \left(180 n_{c}\right)}{2} \\
& A_{c, c}=\frac{n_{c} s_{c}^{2} \cot \left(180 / n_{c}\right)}{4}=A_{c, s h}=\pi\left(t_{c}^{2}+2 a t_{c}\right)
\end{aligned}
$$

Fig. 2. Description of finite element model of thermoseed and catheter Mensuration formulas ((i)-(viii)) [41] are used to determine several distances (e.g., $r_{s}, s_{s}, R_{s}, r_{c}, s_{c}, R_{c}$ ) in the model. The unit length, $i$, is shown in several locations to satisfy conditions requiring per unit area multipliers. Boundary conditions are shown at the control surfaces (dashed lines) on the inner and outer surfaces of the seed and catheter. The seed model has no blood flow, an assumed infinite thermal conductivity, and a uniform temperature $\left(T_{s}\right)$ dependent on power absorbed $\left(q_{a}\right)$. The catheter model is a region of distributed temperature and no blood perfusion.

The transfer of energy from the thermoseed to the surrounding catheter (or tissue, if no catheter is present) is modeled with a conductance coefficient, $h$. The conductance coefficient is used in the seed model because of a software requirement. The product, $h A_{s}$, represents a thermal conductance between a thermoseed and the finite element nodes on the surface of the seed, where $A_{s}$ is the boundary-segment area of a finite element node on the seed surface (Fig. 2). A negligible difference between the temperature of the thermoseed(s) $\left(T_{s}(s)\right)$ and those of the finite element nodes on the seed surface is achieved with $h \geq 10^{6} \mathrm{~W} / \mathrm{m}^{2} /{ }^{\circ} \mathrm{C}$. It is assumed that the thermoseed and catheter are in perfect contact, and therefore, there is no temperature drop across the interface of the seed and catheter models.

With these conditions, the uniform temperature $\left(T_{s}\right)$ of a thermoseed depends on the absorbed power

$$
T_{s}=T_{s}\left(q_{a}\right)=T_{s}\left(\frac{P^{\prime}}{A_{c, d o d}}\right)
$$




\section{B. Modeling the Catheter}

The catheter is modeled as a region of distributed temperature with a thermal conductivity, $k_{c}$, equal to $0.34 \mathrm{~W} / \mathrm{m} /{ }^{\circ} \mathrm{C}$ [42]. The catheter model has no blood perfusion. The crosssectional area of the catheter model, $A_{c, c}$, is equal to the cross-sectional area of an annular shell, $A_{c, s h}$, with a thickness, $t_{c}$, of $0.35 \mathrm{~mm}$ and radial boundaries ${ }^{3} 0.9$ to $1.6 \mathrm{~mm}$. The boundary conditions on the inner and outer edges of the catheter are shown in Fig. 2. With these conditions, the temperature distribution in the catheter is determined with

$$
k_{c} \nabla^{2} T=0 \text {. }
$$

\section{Modeling the Tissue}

Tissue is modeled as a region of distributed temperature with blood profusion. The bioheat transfer equation [39] is used to predict the temperature distribution. The transient time during hyperthermia treatment is often small relative to the steadystate time [23], therefore, steady-state solutions are sought. The steady-state bioheat transfer equation is given by

$$
k_{t} \nabla^{2} T-W c_{b}\left(T-T_{b}\right)=0 .
$$

A complete discussion of the derivation and limitation of the bioheat equation can be found elsewhere [43], [44].

The solution to (5) for the unknown temperatures is solved numerically with the finite element method using Galerkin approach [25], [45]. The method approximates the continuous heat-transfer domain as an array of interconnected, triangularshaped, finite elements within which temperature is assumed to be linear. The solution vector of temperatures is determined with direct techniques using the Cholesky decomposition method [45]. Computational time is reduced by using a bandwidth minimizing routine [46]. The numerical solutions are obtained using a general purpose, finite-element heat-transfer computer program called FEHT (pronounced, "feet") [47].

\section{POWER-VERSUS-TEMPERATURE DEPENDENCE OF THERMOSEEDS}

The rate of heat flow from a thermoseed can be determined from physical properties of the alloy. The heating power per unit length, $P^{\prime}$, of a (infinitely) long cylindrical thermoseed in the presence of an electromagnetic field applied to the cylinder axis is given by [2], [32], [48]

$$
P^{\prime}=\frac{\pi x H_{0}^{2}}{\sigma} \frac{\operatorname{ber}(x) b e r^{\prime}(x)+b e i(x) b e i^{\prime}(x)}{b e r^{2}(x)+b e i^{2}(x)} .
$$

In (6), $H_{0}$ is the amplitude of the magnetic field, $x$ is the induction number and equal to $a \sqrt{\omega \sigma \mu} ; \sigma$ is the electrical conductivity of the thermoseed; $\omega$ is equal to $2 \pi f ; f$ is the frequency of the magnetic field; $\mu$ is the permeability of the ferromagnetic material; ber and bei are Kelvin functions [40]; and $b e r^{\prime}$ and $b e i^{\prime}$ are first derivatives of Kelvin functions [40].

\footnotetext{
${ }^{3}$ The catheter wall thickness of $0.35 \mathrm{~mm}$ is near the maximum thickness that would be used in the clinic. A single, $0.25 \mathrm{~mm}$-wall thick sleeve of tubing surrounded by a second $0.1 \mathrm{~mm}$-wall thick of tubing is sometimes used for after-loading in brachytherapy [24].
}

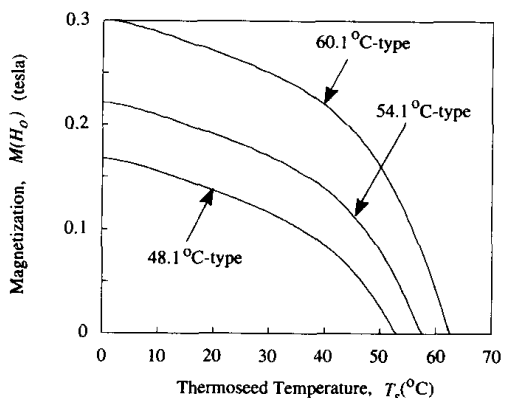

Fig. 3. Magnetization $\left(M\left(H_{0}\right)\right)$ of self-regulating thermoseeds as a function of temperature $\left(T_{s}\right)$. The curve for the $48.1^{\circ} \mathrm{C}$-type seed is reproduced from [2]. The magnetizations of the $54.1^{\circ} \mathrm{C}$ - and $60.1^{\circ} \mathrm{C}$-type seeds are assumed to be larger than the magnetization of $48.1^{\circ} \mathrm{C}$-type seed.

Brezovich et al. [2] reported that an average permeability of $\mathrm{Ni}-\mathrm{Cu}$ thermoseed could be determined with

$$
\mu=\frac{M\left(H_{0}\right)}{H_{0}}+\mu_{0} \text {. }
$$

In (7), $M\left(H_{0}\right)$ is the magnetization at a field intensity of $H_{0}$ and $\mu_{0}$ is the permeability of free space. Equation (7) can be used to evaluate (6) for any desired seed temperature [2]. The error introduced by this simplification is small in the range of hyperthermia temperatures and becomes negligible as the Curie point is reached [2].

The magnetization as a function of temperature for $\mathrm{Ni}$ $\mathrm{Cu}$ thermoseeds with an operating temperature of $48.1^{\circ} \mathrm{C}$ (i.e., a Curie point temperature, $T_{s, c . p .}$, of $53^{\circ} \mathrm{C}$ is shown in Fig. 3. Using the magnetization data of the $48.1^{\circ} \mathrm{C}$-type seed, seed temperature versus power of $48.1^{\circ} \mathrm{C}$-type is computed with (6) (Fig. 4(a)). In the calculation of the absorbed power (6), $\sigma=2.57 \times 10^{6}(\Omega-\mathrm{m})^{-1}, H_{0}=3.98 \times 10^{3} \mathrm{~A} / \mathrm{m}$, $\mu_{0}=10 \times 10^{-7}$ tesla-m/A, $f=90 \mathrm{kHz}$ and $a=0.45 \mathrm{~mm}$.

Since the operating temperature of thermoseeds can be made different by altering the mass function of the diluent, the temperature-versus-power dependence of seeds with (higher) operating temperatures of $54.1^{\circ} \mathrm{C}\left(T_{s, c . p .}=57.6^{\circ} \mathrm{C}\right)$ and $60.1^{\circ} \mathrm{C}\left(T_{s, c . p .}=62.6^{\circ} \mathrm{C}\right)$ are also computed with $(6)$ (Fig. 4(b) ar d (c)). The magnetization of $\left(54.1^{\circ} \mathrm{C}\right.$ - and $60.1^{\circ} \mathrm{C}$ type seeds are assumed to be larger than the magnetization of $48.1^{\circ} \mathrm{C}$-type seed by 0.054 and 0.134 tesla, respectively, over the temperature range shown in Fig. 3 . With the constants 0.054 and 0.134 tesla, $P^{\prime}$ is $10 \mathrm{~W} / \mathrm{m}$ at seed temperatures of 54.1 and $60.1^{\circ} \mathrm{C}$, respectively. In effect, the assumed magnetization-versus-temperature data of $54.1{ }^{\circ} \mathrm{C}$ and $60.1^{\circ} \mathrm{C}$-type seeds shift the power-versus-temperature curve of the $48.1^{\circ} \mathrm{C}$-type seed up and to the right, because for the same absorbed power, seeds with higher operating (or Curie) temperatures should achieve higher temperatures.

An $S$-dimensional Newton-Raphson technique [49], where $S$ is the total number of thermoseeds in the array, is implemented into the finite element solution routine to iteratively determine the temperature of each seed for the power absorbed [25]. In the iteration scheme, the heating power of each seed is initialized at $P^{\prime}{ }_{s, j}$ (seed $s$ and iteration $j$ ), and then the finite element method is used to compute the temperature, $T_{s, j \mathrm{FEHT}}$, 


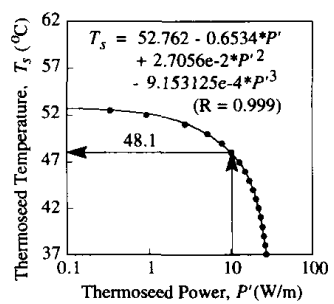

(a)

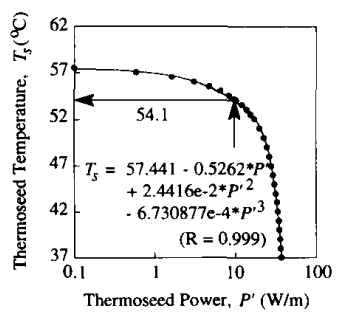

(b)

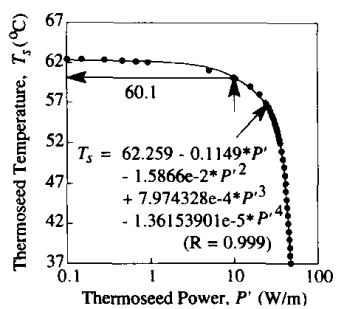

(c)

Fig. 4. Thermoseed temperature $\left(T_{s}\right)$ versus power per unit length $\left(P^{\prime}\right)$ for self-regulating $\mathrm{Ni}-\mathrm{Cu}$ seeds [2] with operating temperatures of (a) $48.1^{\circ} \mathrm{C}$, (b) $54.1^{\circ} \mathrm{C}$ and (c) $60.1^{\circ} \mathrm{C}$. A (reference) power level of $10 \mathrm{~W} / \mathrm{m}$ is used to define the operating temperatures. The data points are generated from theory (6). The solid lines are approximations of that data.

of each seed and the temperature distribution throughout the tissue model. The temperature, $T_{s, j \text { Curve }}$, that each seed would actually produce at $P_{s, j}^{\prime}$ is determined using the temperatureversus-power relationship of the seed (Fig. 4). If $T_{s, j \mathrm{FEHT}}$

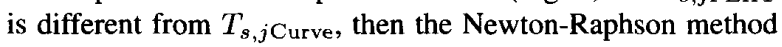
is used to determine the next value of $P_{s, j}^{\prime}$. This procedure is repeated until $T_{s, j \mathrm{FEHT}}$ and $T_{s, j \text { Curve }}$ converge. The convergence criterion is $\left|T_{s, j \mathrm{FEHT}}-T_{s, j \text { Curve }}\right|<$ tol for each thermoseed. A tolerance, tol, of $5 \times 10^{-3 \circ} \mathrm{C}$ is adequate for convergence of the iteration scheme [25].

\section{SimUlations}

Simulations are performed with a 2-D model of a square tissue system ${ }^{4}$. The tissue model consists of a square tumor with an arbitrarily chosen length of $47 \mathrm{~mm}\left(=2 L_{T}\right)$ (Fig. 5). The simulated tumor is implanted with a square $4 \times 4$ array of thermoseeds which is centered squarely within the tumor. The length of the tumor is chosen so that thermoseed spacings, $l$, up to $15 \mathrm{~mm}$ will cover the entire tumor. Since the blood perfusion in the tumor periphery can be quite different than that in the tumor core, the tumor model is divided into a square inner core with a length of $24 \mathrm{~mm}$ surrounded by an outer periphery ${ }^{5}$. The tumor core is centered squarely within the tumor model. The normal tissue has a length of $180 \mathrm{~mm}\left(=2 L_{N}\right)$. The length of the normal tissue is adequate so that the outer edge

${ }^{4}$ The 2-D model is a cross-section near the central plane of the 3-D (parallelpiped) tissue system. The thermoseeds are approximately $65 \mathrm{~mm}$ long. Thus, the tissue model satisfies modeling constraints of 2-D tissue models reported previously [26], [34]

${ }^{5}$ Earlier studies [50] and clinical experience have shown that often, the inner core of the tumor is a tough, fibrous tissue and may have a blood flow that differs vastly from that in the outer periphery of the tumor. Thus, the tumor is modeled as two distinct regions consisting of an inner core and an outer periphery.

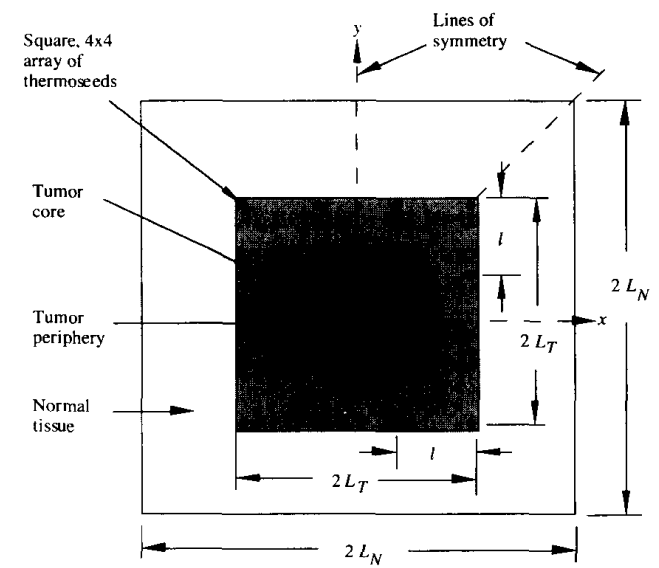

Fig. 5. 2-D cross-section of a square tissue model consisting of a tumor core, tumor periphery and surrounding normal tissue. The lengths of the tumor core, tumor periphery, and normal tissue are $24 \mathrm{~mm}, 47 \mathrm{~mm}\left(=2 L_{t}\right)$ and $180 \mathrm{~mm}$ $\left(=2 L_{n}\right)$, respectively. Thermoseed locations are represented by black circles and are separated uniformly by a distance $l$. Seeds 1,2 and 3 are numbered for reference.

boundary condition does not effect tissue temperatures within the thermoseed array [25]. The boundary temperatures are assumed equal to $T_{b}$. The thermal conductivity in the tumor is assumed equal to that of the surrounding normal tissue $\left(k_{t}=0.64 \mathrm{~W} / \mathrm{m} /{ }^{\circ} \mathrm{C}\right)$.

Using geometrical symmetry conditions, only $1 / 8$ of the tissue model in Fig. 5 is discretized into a mesh of finite elements (Fig. 6). By utilizing these symmetry conditions, the number of seeds in the problem is reduced from 16 to 3 . Thermoseed models are spaced uniformly by $l(9 \mathrm{~mm} \leq l \leq$ $15 \mathrm{~mm}$ ) in the $x$ and $y$ directions. Simulations are performed with blood perfusion rates of 4.77 and $9.54 \mathrm{~kg} / \mathrm{s} / \mathrm{m}^{3}$ in normal tissue and $1.9,4.77$ and $14.3 \mathrm{~kg} / \mathrm{s} / \mathrm{m}^{3}$ in the tumor.

The accuracy of the predicted temperature distributions depends on an adequate size of the finite elements. Therefore, mesh sizes with 730,1530 and 2769 finite elements were investigated [25]. The meshes with 1530 and 2769 finite elements were created by reducing quasi-uniformly the mesh with 730 elements. Finite element reduction was concentrated near the seeds, in the tumor and in the normal tissue, near the boundary of the tumor and normal tissues. The mesh with 1530 finite elements provides sufficient accuracy and is used to predict temperature distributions in the simulations herein [25].

Fractions of tumor greater than $43^{\circ} \mathrm{C}$ are determined by three types of simulations. In the first type of simulation, seed temperatures are determined with the temperature-versuspower relationship (Fig. 4). In the second type, the operating temperatures of the seeds are used as constant-temperature modeling assumptions. Similarly, the third type of simulations uses Curie temperatures as constant-temperature modeling assumptions. The assumption of having constant-temperature seeds in the second and third types of simulations is analogous to having seeds that are perfectly regulating so that their temperatures are independent of absorbed power. 


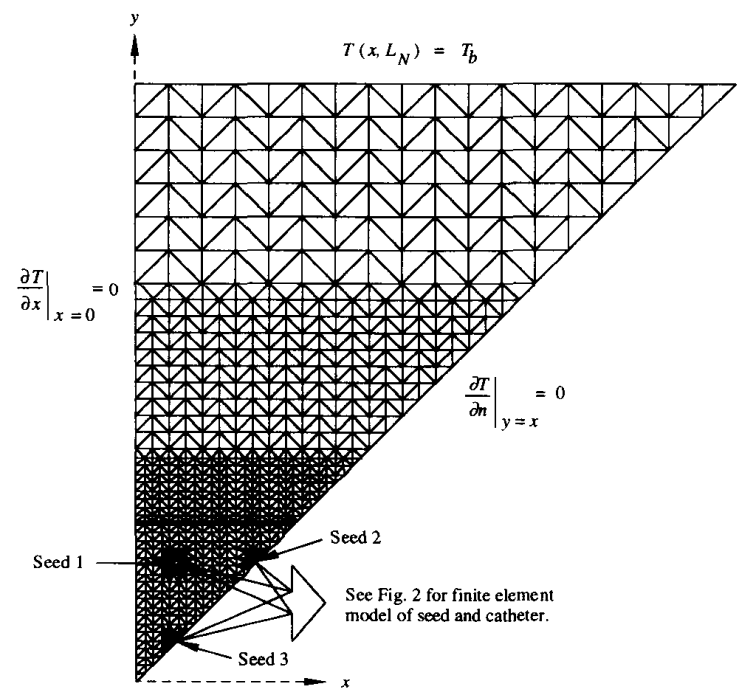

Fig. 6. Finite element mesh of normal and tumor tissue model with adiabatic boundaries ( $x=0$ and $y=x$ ) due to geometric symmetry and a constant-temperature boundary $\left(y=L_{N}\right)$. Blackened areas around the seeds are the result of a finely graded mesh. Seeds are numbered for reference.

In clinical practice, thermoseeds are placed percutaneously into catheter sleeves that have been inserted surgically into the tissue. To study the necessity of modeling catheters, simulations are performed with an array of seeds, each within polyethylene tubing. It is shown later, that with high blood perfusion, a $10 \mathrm{~mm}$ seed spacing heats the largest fraction of tumor above $42^{\circ} \mathrm{C}$. Thus, the seed spacing is $10 \mathrm{~mm}$ in the simulations with seed and catheter models.

\section{Results}

\section{A. Accuracy of Numerical Thermoseed Model}

Temperature distributions computed with the numerical model of a single, $60.1^{\circ} \mathrm{C}$-type seed in the tissue model in Fig. 1 are compared to those of the analytical model (Fig. 7). Thermoseed and tissue temperatures are normalized and displayed for a range of blood perfusions. Seed temperatures are approximately $0.1{ }^{\circ} \mathrm{C}$ higher with the numerical model versus those of the analytical model. Error in the numerical model is from several sources, including the geometric approximation of a circle by a dodecagon, the NewtonRaphson iteration scheme, the boundary condition at the seed-tissue interface, and the size of the finite elements. The seed and tissue temperature distributions in Fig. 7 reveal that the error in the numerical seed model is quite small.

\section{B. Effect of Interseed Spacing and Blood Perfusion on Seed and Tissue Temperatures}

Thermoseed temperatures are plotted in Fig. 8 for simulations with a high rate of blood perfusion. For the same applied field strength, temperatures of all seeds dropped with increased spacing due to the diminishing, seed-to-seed heating effect with wider seed spacings. Temperatures of thermoseeds

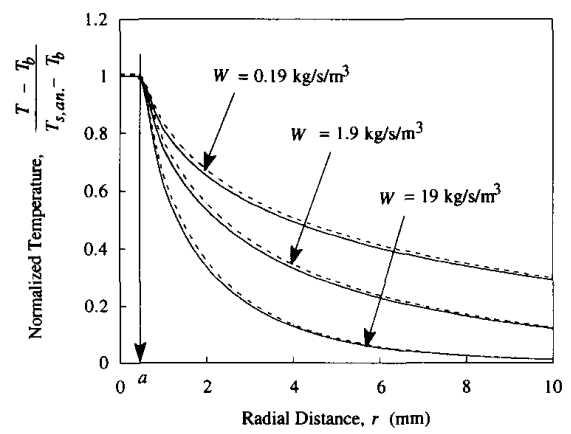

Fig. 7. Normalized temperatures as a function of radial distance over two decades of blood perfusion. Solutions are obtained with the analytical, single seed-in-tissue model (solid lines) and the finite element, dodecagonal seed-in-tissue model (dashed lines). The thermoseed has the temperature-versus-power dependence of the $60.1^{\circ} \mathrm{C}$-type seed. The subscript, an, is the seed temperature computed with the analytical model.

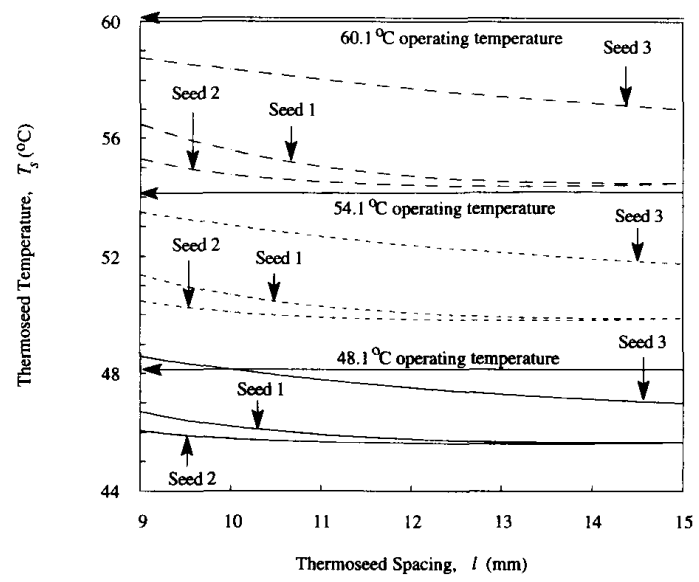

Fig. 8. Effect of interseed spacing on seed temperatures in simulations with a two-comparment, high-rate, tumor blood perfusion model ( $W_{t}$,core $\left.=1.9 \mathrm{~kg} / \mathrm{s} / \mathrm{m}^{3}, W_{t \text {, perip }}=14.3 \mathrm{~kg} / \mathrm{s}^{\mathrm{m}} \mathrm{m}^{3}, W_{n}=9.54 \mathrm{~kg} / \mathrm{s} / \mathrm{m}^{3}\right)$. In these simulations, seed models have temperature-versus-power dependencies with operating temperatures of $48.1^{\circ} \mathrm{C}$ (solid lines), $54.1^{\circ} \mathrm{C}$ (short-dashed lines) and $60.1^{\circ} \mathrm{C}$ (long-dashed lines). For locations of seeds 1,2 and 3 , refer to Figs. 5 and 6.

1 and 2 dropped between one and two degrees over speed spacings between 9 and $13 \mathrm{~mm}$, while the temperature of seed 3 continued to decrease beyond an $l$ of $13 \mathrm{~mm}$.

In simulations with all three types of seeds, a seed spacing of $10 \mathrm{~mm}$, and tumor perfusion of $1.91 \mathrm{~kg} / \mathrm{s} / \mathrm{m}^{3}$, the temperature of thermoseed 2 decreases by $0.3^{\circ} \mathrm{C}$ as normal tissue blood perfusion increases by an order-of-magnitude from 1.9 to 19 $\mathrm{kg} / \mathrm{s} / \mathrm{m}^{3}$ [25]. The temperature of seed 2 drops by $1.4,1.8$ and $2.1^{\circ} \mathrm{C}$ in simulations with arrays of $48.1^{\circ} \mathrm{C}-, 54.1^{\circ} \mathrm{C}$ - and $60.1^{\circ} \mathrm{C}$-type seeds, respectively, with a spacing of $15 \mathrm{~mm}$. In simulations with all three types of arrays and with seed spacing of $10 \mathrm{~mm}$, the temperature of thermoseed 2 in the tumor with blood perfusion of $4.77 \mathrm{~kg} / \mathrm{s} / \mathrm{m}^{3}$ is approximately $1{ }^{\circ} \mathrm{C}$ lower than the temperature predicted with tumor perfusion of 1.9 $\mathrm{kg} / \mathrm{s} / \mathrm{m}^{3}$. The temperature of seed 2 , over the same decrease in tumor perfusion from 4.77 to $1.9 \mathrm{~kg} / \mathrm{s} / \mathrm{m}^{3}$, decreases by about $0.4^{\circ} \mathrm{C}$ with a seed spacing of $15 \mathrm{~mm}$ [25]. 


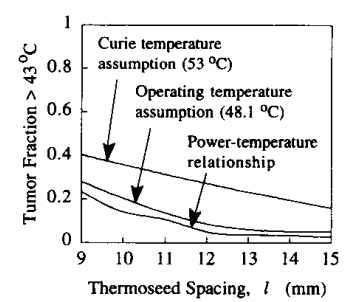

(a)

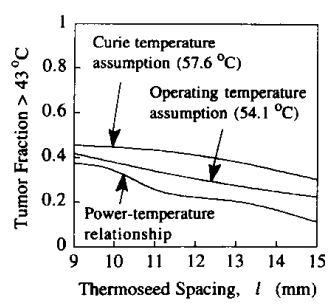

(b)

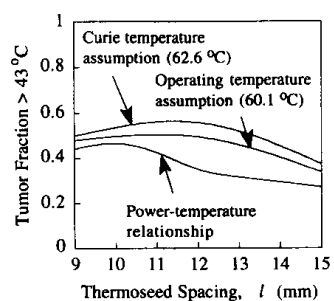

(c)

Fig. 9. Fraction of tumor above $43^{\circ} \mathrm{C}$ versus seed spacing from simulations with arrays of (a) $48.1^{\circ} \mathrm{C}$-, (b) $54.1^{\circ} \mathrm{C}$ - and (c) $60.1^{\circ} \mathrm{C}$-type seeds. Simulations are performed for cases where seed temperatures depend on power and with constant-temperature (Curie and operating temperatures) modeling assumptions. Simulations are performed with a two-compartment, high-rate, tumor blood perfusion model $\left(W_{t, \text { core }}=1.9 \mathrm{~kg} / \mathrm{s} / \mathrm{m}^{3}, W_{t}\right.$, perip $=14.3 \mathrm{~kg} / \mathrm{s} / \mathrm{m}^{3}$, $\left.W_{n}=9.54 \mathrm{~kg} / \mathrm{s} / \mathrm{m}^{3}\right)$.

Fractions of tumor greater than $43^{\circ} \mathrm{C}$ in simulations with an array of $48.1^{\circ} \mathrm{C}$-type seeds are between 16 and $45 \%$ lower over all seed spacings, when seed temperatures depend on power versus models which assume constant seed temperatures (Fig. 9(a)). Similarly, tumor fractions greater than $43^{\circ} \mathrm{C}$ in simulations with $54.1^{\circ} \mathrm{C}$ - and $60.1^{\circ} \mathrm{C}$-type seeds are between 10 and $50 \%$ and between 8 and $40 \%$ lower, respectively, over all seed spacing (Fig. 9(b) and (c)). Results in Fig. 9 represent a worst case scenario, where the tissue model is highly perfused. Examples of seed configurations that adequately heat the tumor for several blood perfusion models are discussed next.

The effect of seed type and interseed spacing on fractions of tumor greater than $42^{\circ} \mathrm{C}$ for several perfusion models are shown in Fig. 10. Generally, these curves have a maximum indicating a desired seed spacing for a particular seed type and perfusion model. Tumor fractions greater than $42^{\circ} \mathrm{C}$ decrease with seed spacings narrower than the optimum due to insufficient heating of the tumor outside the array of seeds. The diminishing ability to heat tumor greater than $42^{\circ} \mathrm{C}$ with seed spacings wider than the optimum is due to cooler tissue temperatures between seeds. Arrays of $48.1^{\circ} \mathrm{C}$-type seeds do not adequately heat the tumor for any of the perfusion models studied. Arrays of $54.1^{\circ} \mathrm{C}$-type seeds sufficiently heat the tumor only for low blood perfusion cases (Fig. 10(a) and (b)). Arrays of $60.1^{\circ} \mathrm{C}$-type seeds heat the entire tumor to temperatures above $42^{\circ} \mathrm{C}$ for low and moderate perfusion cases (Fig. 10(a), (b) and (c)). The $60.1^{\circ} \mathrm{C}$-type array also nearly heats the entire tumor to temperatures above $42^{\circ} \mathrm{C}$ in the case of high perfusion in normal tissue (Fig. 10(d)). The array of

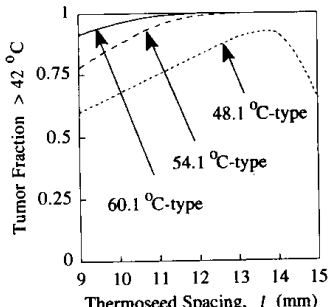

(a)

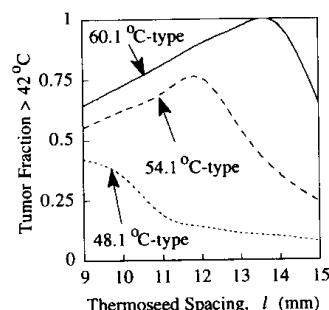

(c)

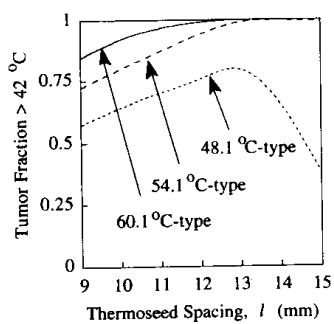

(b)

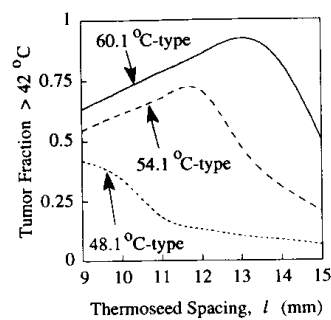

(d)

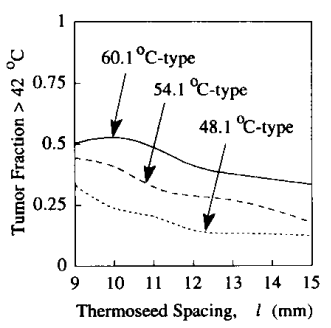

(e)

Fig. 10. Fraction of tumor above $42^{\circ} \mathrm{C}$ versus seed spacing from simulations with arrays of $48.1^{\circ} \mathrm{C}$-, $54.1^{\circ} \mathrm{C}$ - and $60.1^{\circ} \mathrm{C}$-type seeds. Simulations are performed for two uniform ((a) and (c)) and three nonuniform ((b), (d) and (e)) blood perfusion models. All blood perfusion rates $\left(W_{t, \text { core }} / W_{t, \text { perip }} / W_{n}\right)$ are given in units of $\mathrm{kg} / \mathrm{s} / \mathrm{m}^{3}$. Seeds are modeled without catheters and seed temperatures depend on the power absorbed.

$60.1^{\circ} \mathrm{C}$-type seeds does not heat the tumor very well when normal tissue is highly perfused and when perfusion in the tumor periphery is $150 \%$ of that in normal tissue (Fig. 10(e)).

\section{Effect of Catheter Model on Heating Tumor Tissue}

Average temperature decreases through catheter walls are between 1.7 and $6.8^{\circ} \mathrm{C}$ (Fig. 11(a)). Temperatures through the catheter wall surrounding $48.1^{\circ} \mathrm{C}$-type seeds decrease between 1.7 and $3.4^{\circ} \mathrm{C}$ over an increase in blood perfusion from a lowrate to a high-rate model. The temperature decreases through the catheters are larger with higher temperature seeds. Temperatures through the catheter wall surrounding $54.1^{\circ} \mathrm{C}$-type seeds decrease by 2.5 to $5.0^{\circ} \mathrm{C}$, while temperatures drop between 3.2 and $6.8^{\circ} \mathrm{C}$ through catheter walls surrounding $60.1^{\circ} \mathrm{C}$ type seeds. Because of the temperature decrease through the catheters, the fractions of tumor greater than $42^{\circ} \mathrm{C}$ in simulations with seed and catheter models are between 3.3 and $25 \%$ lower over all seed types than in simulations with bare seeds (Fig. 11(b)). 


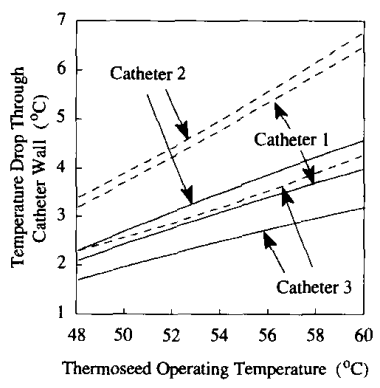

(a)

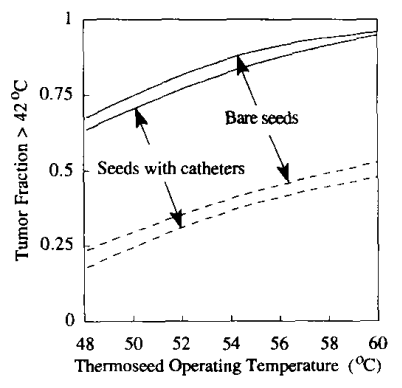

(b)
Fig. 11. Effect of catheter models on (a) temperature decrease through catheters and (b) fractions of tumor at temperatures above $42^{\circ} \mathrm{C}$. Results are shown for a range of seed types and for low-rate (solid lines: $W_{t}$ core $=W_{t}$. perip $=1.9 \mathrm{~kg} / \mathrm{s} / \mathrm{m}^{3}, W_{n}=4.77 \mathrm{~kg} / \mathrm{s} / \mathrm{m}^{3}$ ) and high-rate (dashed lines: $W_{t}$, core $\left.=1.9 \mathrm{~kg} / \mathrm{s} / \mathrm{m}^{3}, W_{t, \text { perip }}=14.3 \mathrm{~kg} / \mathrm{s} / \mathrm{m}^{3}, W_{n}=9.5 \mathrm{~kg} / \mathrm{s} / \mathrm{m}^{3}\right)$ blood perfusion models. See Figs. 5 and 6 for locations of catheters 1, 2 and 3 .

\section{DISCUSSION}

In addition to the dodecagonally shaped, finite element seed model presented herein, a seed model in the shape of a regular hexagon was studied [25]. It has been shown that the temperature distributions predicted by the hexagonal and dodecagonal seed models are quite similar [25]. The dodecagonal seed model is the preferred model because its cross-sectional shape more closely resembles the shape of a cylindrical thermoseed.

In a theoretical study with constant-temperature seeds, the periphery of a tissue model outside the thermoseed array did not heat as well as tissue between seeds [27]. The study suggests that the periphery of a thermoseed array may be a likely site for placing seeds with higher temperatures [27]. Stauffer [51] has made a similar suggestion. Results from the present study, where the power-versus-temperature dependence of seeds is used in modeling, reveal that seeds furthest from the center of the array absorb more power and are cooler than seeds closer to the center of the array (Fig. 8). Thus, the reported findings [27] that the tumor periphery is a likely site for seeds with higher temperatures are supported by the results herein.

It has been reported by Haider et al. [35] that the effect of a $0.25 \mathrm{~mm}$-wall catheter on tissue temperature is minimal, so long as the thermal conductivity of the catheter $\left(k_{c}=0.35\right.$ $\left.\mathrm{W} / \mathrm{m} /{ }^{\circ} \mathrm{C}\right)$ is near that of tissue $\left(k_{t}=0.5 \mathrm{~W} / \mathrm{m} /{ }^{\circ} \mathrm{C}\right)$. Results from the present study are in contrast with those of Haider et al. [35]. The decreases in temperature through the 0.35 mm-wall catheter $\left(k_{c}=0.34 \mathrm{~W} / \mathrm{m} /{ }^{\circ} \mathrm{C}\right)$ are between 1.7 and $6.8^{\circ} \mathrm{C}$ over a range of blood perfusion models and seed types. The fraction of tumor $\left(k_{t}=0.64 \mathrm{~W} / \mathrm{m} /{ }^{\circ} \mathrm{C}\right)$ greater than $42^{\circ} \mathrm{C}$ in simulations using seed and catheter models are between 3.3 and $25 \%$ lower than in simulations with bare seeds (Fig. 11(b)). The thicker sleeve $(0.35$ versus $0.25 \mathrm{~mm}$ [35]) and higher tissue thermal conductivity $(0.64$ versus 0.5 $\left.\mathrm{W} / \mathrm{m} /{ }^{\circ} \mathrm{C}[35]\right)$ may account for the differences between the results herein and those reported by Haider et al. [35] on the effect of catheters on tissue temperature. Tissue temperature predictions should better approximate temperature distribu- tions in an actual treatment if catheter models, comparable to the thickness and thermal conductivity in the present study, are included in computer simulations. It is possible, however, that modeling catheters would be unnecessary in simulating treatments that use catheters made of a material with a high thermal conductivity.

A general, treatment planning program has been used to analyze the 3-D temperature distributions generated by an array of ferromagnetic seeds in a tissue model assumed to be uniformly perfused [36]. It has been reported that in moderate perfusion cases $\left(W<5 \mathrm{~kg} / \mathrm{s} / \mathrm{m}^{3}\right.$ ), good temperature distributions are generated using $60^{\circ} \mathrm{C}$ Curie point seeds and 10-mm spacing [36]. In larger blood perfusion cases, however, it has been reported that higher Curie point seeds, seeds that extend beyond the tumor length, and small seed spacings $(<10 \mathrm{~mm})$ should be used to heat tissue temperatures within the seed array above $42^{\circ} \mathrm{C}$ [36]. Generally, the findings of these investigators [36] are supported by results from the present study. The entire tumor is heated to temperatures above $42^{\circ} \mathrm{C}$ with $62.6^{\circ} \mathrm{C}$ Curie point seeds in tissue with either uniform or nonuniform perfusion models and with low to moderate perfusion rates ( $W \leq 4.77 \mathrm{~kg} / \mathrm{s} / \mathrm{m}^{3}$ ) (Fig. 10(a), (b) and (c)). In simulations with the high blood perfusion model, significantly lower fractions of tumor are heated to temperatures above $42^{\circ} \mathrm{C}$ (Fig. 10(e)). In this case, it should be possible to obtain higher interseed tissue temperatures by using more seeds (e.g., $5 \times 5$ ) with seed spacings of about $10 \mathrm{~mm}$. The use of seeds with higher Curie points $\left(>62.6^{\circ} \mathrm{C}\right)$ is another design consideration that would achieve higher interseed tissue temperatures in cases of high blood perfusion.

Predictions of seed and tissue temperatures at the midplane cross-section perpendicular to the long axes of the seeds have been reported previously [34]. In a parametric simulation study investigating the effect of various blood perfusions and seed lengths in 2- and 3-D tissue models, seed and interseed tissue temperatures were between 0.1 and $8^{\circ} \mathrm{C}$ higher for the 2-D than for the 3-D tissue model [34]. Differences between temperatures in the 2- and 3-D models diminished with increasing blood perfusion, and at the midplane cross-section with increasing seed length [34]. Thus, seed and tissue temperatures and fractions of tumor greater than $42^{\circ} \mathrm{C}$ predicted in the present study are probably higher than those which would be predicted with a 3-D tissue model. Nevertheless, the modeling trends from the simulations performed in the present study including 1) the need to model the self-regulating feature of thermoseeds, 2) higher power absorption and lower temperature seeds on the periphery of an implant array, and 3) a modestly lower fraction of tissue above $42{ }^{\circ} \mathrm{C}$ in simulations with models of seeds and catheters versus models of bare seeds, should remain consistent between simulations of 2- and 3-D tissue models.

In summary, finite element heat-transfer models of ferromagnetic thermoseeds and catheters are developed for simulating ferromagnetic hyperthermia. The seed and catheter models have fewer modeling constraints than other previously developed thermal models. Simulations are performed with $4 \times 4$ array of seeds in a multicompartment tissue model. It is demonstrated that using Curie or operating temperatures 
as constant-temperature modeling assumptions versus models where seed temperatures depend on the power absorbed can modestly, and sometimes significantly, overpredict tissue heating. It is shown that fractions of tumor heated to temperatures above a minimum therapeutic level in simulations using seed and catheter models can be modestly higher than in simulations with bare seeds. It is also demonstrated that an array of seeds with Curie points of $62.6^{\circ} \mathrm{C}$ heats the tumor very well over nearly all blood perfusion cases studied.

\section{REFERENCES}

[1] W. J. Atkinson, I. A. Brezovich, and D. P. Chakraborty, "Usable frequencies in hyperthermia with thermal seeds," IEEE Trans. Biomed. Eng., vol. 31, pp. 70-75, 1984.

(2] I. A. Brezovich, W. J. Atkinson, and D. P. Chakraborty, "Temperature distributions in tumor models heated by self-regulating nickel-copper alloy thermoseeds," Med. Phys., vol. 11, pp. 145-152, 1984.

[3] T. Kobayashi, Y. Kida, T. Tanaka, N. Kageyama, H. Kobayashi, and Y. Amemiya, "Magnetic induction hyperthermia for brain tumor using ferromagnetic implant with low Curie temperature," J. Neuro-Oncol. vol. 4, pp. 175-181, 1986

[4] P. R. Stauffer, T. C. Cetas, A. M. Fletcher, D. W. DeYoung, J. R. Oleson, and R. B. Roemer, "Observations in the use of ferromagnetic implants for inducing hyperthermia," IEEE Trans, Biomed. Eng., vol. 31. pp. 76-90, 1984

[5] M. A. Astrahan and A. Norman, "A localized current field hyperthermia system for use with 192-iridium interstitial implants," Med. Phys., vol 9, pp. 419-424, 1982

[6] B. Emarni, C. A. Perez, L. Leybovich, W. Straube, and D. Vongerichten, "Interstitial thermoradiotherapy in treatment of malignant tumors," Int. J. Hyperthermia, vol. 3 pp. 107-118, 1987

[7] P. R. Stauffer, "Simple RF matching network for conversion of electrosurgical units or laboratory amplifiers to hyperthermia treatment devices," Med. Instrum., vol. 18, pp. 326-328, 1984

[8] J. W. Strohbehn, "Temperature distributions from interstitial RF electrode hyperthermia systems: Theoretical predictions," Int. J. Radiation Oncol. Biol. Phys., vol. 9, pp. 1655-1667, 1983.

[9] N. Vora, B. Forell, C. Joseph, J. Lipsett, and J. Archambeau, "Interstitial implant with interstitial hyperthermia," Cancer, vol. 50, pp. 2518-2523, 1982

[10] X. L. Zhu and O. P. Gandhi, "Design of RF needle applicators for optimum SAR distributions in irregularly shaped tumors," IEEE Trans. Biomed. Eng., vol. 35, pp. 382-388, 1988.

[11] C. T. Coughlin, T. Z. Wong, J. W. Strohbehn, T. A. Colacchhio, J. E. Sutton, R. Z. Belch, and E. B. Douple, "Intraoperative interstitia microwave-induced hyperthermia and brachytherapy," Int. J. Radiation Oncol. Biol. Phys., vol. 11, pp. 1673-1678, 1985.

[12] M. Salcman and G. M. Samaras, "Interstitial microwave hyperthermia for brain tumors: Results of phase-I clinical trial,"J. Neuro-Oncol., vol. 1, pp. $225-236,1983$

[13] T. Satoh and P. R. Stauffer, "Implantable helical coil microwave antenna for interstitial hyperthermia," Int. J. Hyperthermia, vol. 4, pp. 497-512, 1988

[14] J. W. Strohbehn, E. Bowers, J. Walsh, and E. B. Douple, "An invasive microwave antenna system for locally-induced hyperthermia for cancer therapy," J. Microwave Power, vol. 14, pp. 339-350, 1979.

[15] I. A. Brezovich, R. F. Meredith, R. A. Henderson, W. R. Brawner, B. Weppelmann, and M. M. Salter, "Hyperthermia with water-perfused catheters," in Hyperthermic Oncology, J. Overgaard, Ed. London: Taylor and Francis, 1989, pp. 809-810.

[16] K. Schreier, M. Budihna, H. Lesnicar, L. Handl-Zeller, J. W. Hand, M. V. Prior, S. T. Clegg, and I. A. Brezovich, "Preliminary studies of interstitial hyperthermia using hot water," Int. J. Hyperthermia, vol. 6, pp. $431-444,1990$

[17] N. Daikuzono, S. N. Joffe, H. Tajiri, S. Suzuki, H. Tsunekawa, and M Ohyama, "Laserthermia: A computer-controlled contact Nd:YAG system for interstitial local hyperthermia," Med. Instrum., vol. 21, pp. 275-277, 1987.

[18] C. F. Babbs, N. E. Fearnot, J. A. Marchosky, C. J. Moran, J. T. Jones, and T. D. Plantenga, "Theoretical basis for controlling minimal tumor temperature during interstitial conductive heat therapy," IEEE Trans. Biomed. Eng., vol. 37, no. 7, pp. 662-672, 1990.

[19] J. S. Chen, D. R. Poirier. M. A. Damento, L. J. Demer, F. Biencaniellow, and T. C. Cetas, "Development of Ni-4 weight percent $\mathrm{Si}$ thermoseeds for hyperthermia cancer treatment," J. Biomaterials Res., vol. 22, pp. 303-319, 1988.

[20] J. R. Oleson and T. C. Cetas, "Clinical hyperthermia with RF currents," in Physical Aspects of Hyperthermia, G. H. Nussbaum, Ed. New York, NY: Amer. Inst. Physics, 1982, pp. 280-306.

21] C. V. Burton, M. Hill, and A. E. Walker, "The RF thermoseed-A thermally self-regulating thermoseed," IEEE Trans. Biomed. Eng., vol. 18, pp. 104-109, 1971.

[22] R. A. Moidel, S. K. Wolfson, R. G. Selker, and S. B. Weiner, "Materials for selective tissue heating in a radiofrequency electromagnetic field or the combined chemothermal treatment of brain tumors," J. Biomed. Materials Res., vol. 10, pp. 327-334, 1976.

[23] B. P. Partington, R. A. Steeves, S. L. Su, B. R. Paliwal, R. R. Dubielzig, J. W. Wilson, and I. A. Brezovich, "Temperature distributions, microangiographic and histopathologic correlations in normal tissue heated by ferromagnetic needles," Int. J. Hyperthermia, vol. 5, pp. 319-327, 1989.

[24] D. T. Tompkins, B. P. Partington, R. A. Steeves, S. D. Bartholow, and B. R. Paliwal, "Effect of implant variables on temperatures achieved during ferromagnetic hyperthermia," Int. J. Hyperthermia, vol. 8, pp. 241-251, 1992.

[25] D. T. Tompkins, "A finite element heat transfer model of ferromagnetic thermoseeds and a physiologically-based objective function for pretreatment planning of ferromagnetic hyperthermia," Ph.D. dissertation, Dep. Mech. Eng., Univ. Wisconsin-Madison, Madison, WI, 1992.

[26] R. B. Chin and P. R. Stauffer, "Treatment planning for ferromagnetic seed heating," Int. J. Radiation Oncol. Biol. Phys., vol. 21, pp. 431-439, 1991.

[27] J. A. Mechling and J. W. Strohbehn, "A theoretical comparison of the temperature distributions produced by three interstitial hyperthermia systems," Int. J. Radiation Oncol. Biol. Phys., vol. 12, pp. 2137-2149, 1986.

[28] R. Vanderby, B. R. Paliwal, R. T. Wakai, D. M. Belloli, B. P. Partington, R. A. Steeves, and J. P. Heiner, "A parametric study of temperature distributions in ferromagnetic hyperthermia," in Computational Method in Bioengineering, vol. BED-9, R. L. Spilker and B. R. Simon, Eds. New York, NY: Amer. Society Mech. Eng., 1988, pp. 291-299.

[29] A. Y. Matloubieh, R. B. Roemer, and T. C. Cetas, "Numerical simulation of magnetic induction heating of tumors with ferromagnetic seed implants," IEEE Trans. Biomed. Eng., vol. 31, pp. 227-234, 1984.

[30] P. R. Stauffer, T. C. Cetas, and R. C. Jones, "Magnetic induction heating of ferromagnetic implants for inducing localized hyperthermia in deep-seated tumors," IEEE Trans. Biomed. Eng., vol. 31, pp. 235-251, 1984

[31] S. A. Haider, "Ferromagnetic implants in hyperthermia: An analytical, numerical and experimental study," M.S. thesis, Dep. Elec. Comp. Eng., Univ, Arizona, Tucson, AZ, 1988.

[32] S. A. Haider, T. C. Cetas, J. R. Wait, and J. S. Chen, "Power absorption in ferromagnetic implants from radiofrequency magnetic field and the problem of optimization," IEEE Trans. Microwave Theory Tech., vol. 39, pp. 1817-1827, 1991.

[33] Z. P. Chen, "Three-dimensional hyperthermia cancer treatment simulation," Ph.D. dissertation, Dep. Aerospace Mech. Eng., Univ. Arizona, Tucson, AZ, 1989.

[34] Z. P. Chen, R. B. Roemer, and T. C. Cetas, "Errors in the 2-D simulation of ferromagnetic implant hyperthermia," Int. J. Hyperthermia, vol. 7 , pp. 735-739, 1991.

[35] S. A. Haider, T. C. Cetas, and R. B. Roemer, "Temperature distribution in tissues from a regular array of hot source implants: An analytical approximation," IEEE Trans. Biomed. Eng., vol. 40, no. 5, pp. 408-417, 1993.

[36] Z. P. Chen, R. B. Roemer, and T. C. Cetas, "Three-dimensional simulations of ferromagnetic implant hyperthermia," Med. Phys., vol. 19, no. 4, pp. 989-997, 1992.

[37] R. K. Jain, "Bioheat transfer: Mathematical models of thermal systems," in Hyperthermia in Cancer Therapy, F. K. Storm, Ed. Boston, MA: G K. Hall Med. Publ., 1983, pp. 9-46.

[38] F. P. Incropera and D. P. DeWitt, Introduction to Heat Transfer. New York: Wiley, 1985.

[39] H. H. Pennes, "Analysis of tissue and arterial blood temperatures in the resting human forearm," J. Applied Physiol., vol. 1, pp. 93-122, 1948.

[40] M. B. Abramowitz and I. A. Stegun, Eds., Handbook of Mathematical Functions With Formulas, Graphs, and Mathematical Tables. New York: Dover, 1964, pp. 358-433.

[41] W. H. Beyer, Ed., CRC Standard Mathematical Tables. Boca Raton, FL: CRC Press, 1981, p. 122

[42] Clay Adams Co., Parsippany, NJ, private communication.

[43] H. F. Bowman, E. C. Cravalho, and M. Woods, "Theory, measurement, and application of thermal properties of biomaterials," Ann. Rev. 
Biophys. Bioeng., vol. 4, pp. 43-80, 1975.

[44] R. B. Roemer, "Heat transfer in hyperthermia treatments: Basic principles and applications," in Biological, Physical and Clinical Aspects of Hyperthermia, B. R. Paliwal, F. W. Hetzel, and M. W. Dewhirst, Eds. New York, NY: Amer. Inst. Physics, 1988, pp. 210-242.

[45] G. E. Myers, "Numerical methods of solving heat conduction equation (ME 764)," Course notes, Mech. Eng. Dep., Univ. Wisconsin, Madison, WI.

[46] R. J. Collins, "Bandwidth reduction by automatic renumbering," Int. $J$. Numer. Methods Eng., vol. 6, pp. 345-356, 1973.

[47] S. A. Klein, W. A. Beckman, and G. E. Myers, "FEHT: Finite Element Heat Transfer computer program," F-chart Software, Middleton, WI.

[48] E. J. Davies and P. Simpson, Induction Heating Handbook. London, England: McGraw-Hill, 1979, pp. 307-340.

[49] T. E. Shoup, A Practical Guide to Computer Methods for Engineers. Englewood Cliffs, NJ: Prentice-Hall, 1979, pp. 33-36.

[50] P. Falk, "Patterns of vasculature in pairs of fibrosarcoma in the rat and their relation to tumor response to single large doses of radiation," Eur. J. Cancer, vol. 14, pp. 237-250, 1978

[51] P. R. Stauffer, "Techniques for interstitial hyperthermia," in Introduction to the Practical Aspects of Clinical Hyperthermia, S. B. Field and J. W. Hand, Eds. Philadelphia, PA: Taylor and Francis, 1990, pp. 344-370.

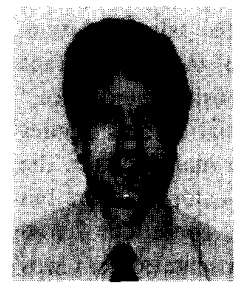

Dean T. Tompkins received the B.S. (1984), M.S (1988) and Ph.D. (1992) degrees in mechanical engineering from the University of WisconsinPlatteville (B.S.) and -Madison (M.S. and Ph.D.).

$\mathrm{He}$ is a Research Scientist in the Engineering Department at the University of WisconsinMadison. His research interests are in bioheat and mass transfer and indoor air quality.

Ray Vanderby received the B.S., M.S. and Ph.D. degrees from Purdue University.

He is Associate Professor of Orthopedic Surgery at the University of Wisconsin-Madison. His interests are in experimental and computational research projects focused on orthopedic biomechanics. Other research interests include computational bioheat transfer.

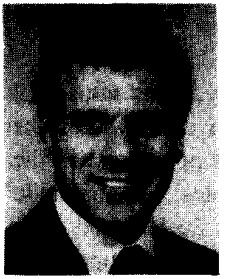

Sandy A. Klein received the B.S. degree in chemical engineering in 1972 from the University of Illinois. He received M.S. and Ph.D. degrees in 1973 and 1976 from the University of WisconsinMadison.

$\mathrm{He}$ is Professor of Mechanical Engineering at the University of Wisconsin-Madison. His research interests are in solar energy processes and absorption processes.

Dr. Klein has won numerous awards for excellence in research, teaching and software development

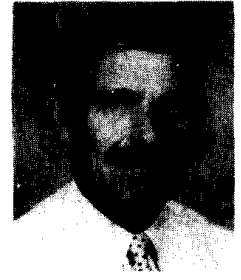

William A. Beckman received B.S. (1958), M.S. (1960) and Ph.D. degrees (1964) in mechanical engineering from the University of Michigan.

$\mathrm{He}$ is Bascom Ouweneel Professor of Mechanical Engineering at the University of WisconsinMadison. Since 1988, he has been the Director of the University of Wisconsin's Solar Energy Laboratory. He was Chairman of the University of Wisconsin Mechanical Engineering Department from 1987-91. His research interests are in solar energy processes and radiation heat transfer.

Dr. Beckman has won numerous awards for excellence in research, teaching and software development.

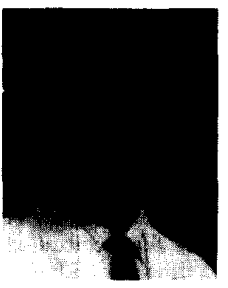

Richard A. Steeves received a medical degree at the University of Western Ontario and the Ph.D. in medical biophysics at the University of Toronto. He studied radiation oncology at the Albert Einstein College of Medicine in Bronx, New York.

Since 1980 , he has been on the faculty at the University of Wisconsin-Madison where he specializes in hyperthermia and the treatment of breast cancer. and has numerous publications in these areas.

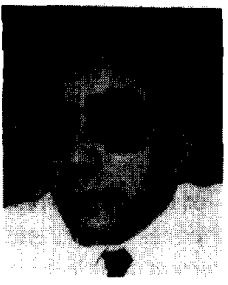

Bhudatt R. Paliwal received the M.S. (1962) de gree in physics from the Sri Aurobindo International Center in India. He received the Ph.D. (1973) degree in biophysics from the University of Texas in Houston, TX.

$\mathrm{He}$ is Professor of Medical Physics and Human Oncology at the University of Wisconsin-Madison. $\mathrm{He}$ has numerous publications in the areas of medical physics and hyperthermia. 